\title{
Web-based dental trauma database using Eden Baysal dental trauma index: a turkish multicenter study
}

\section{Purpose}

To describe the prevalence and pattern of traumatic dental injuries (TDIs) among Turkish children in a web-based and multicenter design using Eden Baysal Dental Trauma Index (EBDTI).

\section{Materials and Methods}

The study sample consisted dental trauma patients aging 1-15 years and a webbased form was developed and used to record the information of the patients' clinical and radiographic findings including EBDTI. The obtained data also included patient gender, age at the initial date of trauma, date of trauma, cause of injury and emergency treatment. Data were analyzed using Pearson Chi-square and Fisher's exact tests.

\section{Results}

A total of 280 traumatized teeth in 252 patients were evaluated. Dental trauma was seen more in boys and $7-10$ years age group $(p<0.05)$. There were significant differences between permanent and deciduous teeth with regard to uncomplicated and complicated crown fracture rate $(p<0.05)$. The root fractures were mostly located at the apical third of the root in both dentitions.

\section{Conclusion}

TDI was associated with age, gender, and type of dental trauma. EDBTI provided easy and proper recording of multiple dental injuries and maturity of the apex and it was found to be a very useful tool to facilitate online recordings of dental injuries.

Keywords: Dental trauma, Eden Baysal Dental Trauma Index, Traumatic dental injuries, Web-based data

\section{Introduction}

Traumatic dental injuries (TDIs) are mostly seen in childhood. A recent meta-analysis showed that one-billion living people had a traumatic injury (1). This huge burden of traumatic dental injuries has impact on quality of life of individuals and may need costly lifelong treatment (2-5). Epidemiological studies on dental trauma are limited with the information obtained from cross-sectional and prospective studies (6). The findings on frequency and distribution of trauma types and its relation with age and gender may help researchers to improve guidelines and stakeholders to plan oral health policies for the target populations. A major obstacle in reporting is the lack of standardization about the classifications of the dental injuries and sample size $(7,8)$.

The reported dental trauma prevalence for primary and permanent dentitions in the literature varies by study populations, region, seasonal changes, and methodology (9-16). The frequency of traumatic dental injuries according to the type has also been reported by retrospective

\author{
Ece Eden ${ }^{1} \mathbb{D}$, \\ Burak Buldur ${ }^{2}$ (D), \\ Gulsum Duruk ${ }^{3}$ (D), \\ Sibel Ezberci ${ }^{4}$
}

ORCID IDs of the authors: E.E. 0000-0001-8427-0427; B.B. 0000-0003-4764-819X; G.D. 0000-0002-6756-6637; S.E. 0000-0002-9303-8360

'Department of Pediatric Dentistry, Faculty of Dentistry, Ege University, Izmir, Turkey

${ }^{2}$ Department of Pediatric Dentistry, Faculty of Dentistry, Cumhuriyet University, Sivas, Turkey

${ }^{3}$ Department of Pediatric Dentistry, Faculty of Dentistry, Inonu University, Malatya, Turkey

${ }^{4}$ Department of Pediatric Dentistry, Faculty of Dentistry, Uşak University, Uşak, Turkey

Corresponding Author: Burak Buldur

E-mail: bbuldur@gmail.com, bbuldur@cumhuriyet.edu.tr

Received: 6 July, 2020 Revised: 25 August, 2020 Accepted: 5 October, 2020

DOI: 10.26650/eor.20210077 
studies with great variations $(17,18)$. The etiology of TDI and concomitant situations such as age of the patient, location of the traumatic injury and the associated luxation injuries all have tremendous effect on the outcome and prognosis $(4,19)$.

Several classifications were suggested in recording TDI types in the dental literature $(4,17,20,21)$. The most frequently used classification defined by Andreasen (21) can clearly describe the major type of injury. However, it is not possible to describe multiple injuries and other information such as location of the root fracture using classifications. On the other hand, the maturity of the apex or accompanying bone injuries that play an important role in treatment planning can only be recorded separately. Therefore, an index has the advantage of recording multiple dental tissue injuries and accompanying bone fracture and additional data, such as root maturation as in Eden Baysal Dental Trauma Index (EBDTI) (22).

One of the key endpoints of the present study was to obtain data on traumatic dental injuries using the new index, which enables to record trauma type, the characteristics of the patient such as the maturity of the tooth or the accompanying luxation injuries. EBDTI is a five-digit index that defines the type of the injury of the dental hard tissues (crown in relation to the pulp and root), periodontal ligament, and alveolar process, and it also records the maturity of the root apex. The FDI tooth code should be used in parentheses to indicate the injured tooth. This recording gives detailed information on the tooth whereas; all this information will also help the clinician to perform a decision tree for a treatment plan. Another advantage of EBDTI is that it is simple and uses not only numbers but first letters of the words and simple signs that makes it easier to apply and it provides ease of registration even in emergency situations. It is also suitable for computer registration which makes recording even easier for gathering data.

To report survival rate of the traumatized teeth in relation with treatment alternatives, large sample sizes are needed. Many predictors and associated factors such as age, maturity of the apex and accompanying injuries serve in a multifactorial way to improve complications and to have impact on the outcomes. This requires statistical analysis of data from large and multiple centers to understand the importance of known predictors for healing (23). Therefore, multicenter studies will help to gather the appropriate sample size to reach evidence-based conclusions (24). When gathering data from different centers, web-based forms are dependable and provide immediate recording (25).

This web-based and multicenter study that uses EBDTI aimed to utilize a dental trauma database to analyze the pattern of TDIs among Turkish children and show the usability of the index online.

\section{Materials and Methods}

\section{Ethical aspects}

Ethical approval was obtained from Local Ethics Committee of Ege University, Turkey $(\mathrm{No}=18-2 / 38)$. This study followed recommendations of the Declaration of Helsinki and Resolution. Parents / caregivers of research subjects were clarified about the objectives of the study and agreed to their participation by signing the free and informed consent form.

\section{Study sample and design}

The study employed a prospective and descriptive design and was conducted in four cities in Turkey. Maximum variation sampling method was used to obtain study sample and cities have different socioeconomic status and Human Development Index (HDI) (26). The study sample consisted of dental trauma patients aging 1-15 years old, attending these Department of Pediatric Dentistry Clinics between February 2018 and August 2018.

\section{Data collection}

A web-based form was developed and used to record the information of the patients' clinical and radiographic findings from four Universities. Information gathered included patient gender, age at the initial date of trauma, systemic condition, date of trauma, cause of injury, place of the accident, type of TDI, tooth/teeth involved in trauma, and concomitant injuries. Both of TDIs to primary and permanent teeth were included in this study. Cause of injury included falling, strike, sport accident, traffic accident, fighting, violence and others. The emergency treatment was also recorded for each TDIs.

\section{Eden baysal dental trauma index}

Table 1 presents the summary of codes used in EBDTI (22). It contains all the essential clinical registrations of associated injuries according to Andreasen's classification (20) and in addition also records maturity of the root. Data were entered electronically via web-based data form by trained pediatric dentists who were standardized in the clinical and radiographic examination of TDIs according to the EBDTI. A pilot study was performed to confirm the inter and intra agreement of four investigators to use EBDTI. Periapical radiographs and review of all clinical cases by all of investigator finally confirmed the diagnosis before statistical analysis.

\section{Statistical analysis}

Data were analyzed using the Statistical Package for Social Sciences (SPSS for Windows, version 18.0, SPSS Inc., Chicago, IL USA). Bivariate analyses were performed to test the association between sociodemographic and independent variables and dental trauma type and treatment, using the Pearson Chi-square and Fisher's exact tests. The statistical significance level was set at $5 \%$.

Table 2. Distribution of the sample according to age and gender

\begin{tabular}{lcccc} 
Age Group (years) & \multicolumn{2}{c}{ Boys } & \multicolumn{2}{c}{ Girls } \\
\hline & $\mathbf{n}$ & $\%$ & $\mathbf{n}$ & $\%$ \\
\hline $1-3$ & 21 & 14.4 & 14 & 13.2 \\
\hline $4-6$ & 14 & 9.6 & 12 & 11.3 \\
\hline $7-10^{*}$ & 84 & 57.5 & 57 & 53.8 \\
\hline $11-15$ & 27 & 18.5 & 23 & 21.7 \\
\hline Total & 146 & 100.0 & 106 & 100.0 \\
\hline
\end{tabular}

* shows the statistically significance difference among age groups, verified by Chi-squared test, $p=0.021$ 
Table 1. Eden Baysal Dental Trauma Index and its components

\begin{tabular}{|c|c|c|c|c|c|}
\hline & 1st digit & 2nd digit & 3rd digit & 4th digit & 5th digit \\
\hline & Crown Fracture & Root fracture & Luxation injury & Maturity of apex & $\begin{array}{c}\text { Alveolar process } \\
\text { fracture }\end{array}$ \\
\hline \multirow[t]{8}{*}{ No of tooth (FDI) } & 0 to 5 & 0 to 3 & Capital first letters & Small first letters & + or - \\
\hline & $0=$ none & $0=$ none & $\mathrm{N}=$ None & $\mathrm{i}=$ immature & $+=$ presence \\
\hline & $1=$ enamel & $1=$ apical $1 / 3$ & $\mathrm{C}=$ Concussion & $\mathrm{m}=$ mature & - = absence \\
\hline & $2=$ uncomplicated crown & $2=$ middle $1 / 3$ & $S=$ Subluxation & $r=$ resorbed & \\
\hline & $3=$ complicated & $3=$ cervical $1 / 3$ & $\mathrm{E}=$ Extrusive & & \\
\hline & $4=$ uncomplicated crown-root & & $\mathrm{L}=$ Lateral & & \\
\hline & $5=$ complicated crown-root & & $\mathrm{I}=$ Intrusive & & \\
\hline & & & $A=$ Avulsion & & \\
\hline
\end{tabular}

\section{Results}

Data were extracted from pediatric dentistry clinics of four different universities over a 6-month period showed that a total of 252 patients ( 280 teeth) suffered dental trauma. Table 2 shows the distribution of the sample according to age and gender. $57.9 \%(n=146)$ of these patients were male. The distribution of TDIs differed according to gender $(p<0.05)$. The distribution of TDI according to universities in ascending order was as follows: Inonu ( $n=113,44.8 \%)$, Cumhuriyet $(n=78,30.9 \%)$, Ege $(n=38,15.1 \%)$, Usak $(n=23$, 9.2\%).The mean age of patients with dental trauma was $7.87 \pm 3.18$ years (minimum 1, maximum 15). The mostly seen dental trauma age group was $9(17.8 \%, n=50)$ and 8 (13.2\%, $n=37)$. 7-10 yr age group was found to be more subjected to dental trauma $(p=0.021)$. Only $3.9 \%(n=10)$ of the patients had systemic disease, whereas $63.5 \%(n=160)$ had tetanus vaccination. Only $2.8 \%(n=7)$ of the patients had allergic disorders. The mostly seen place where dental trauma occurred were home and school $(n=82,29.3 \%$ and $\mathrm{n}=73,26.1$, respectively).

Table 3 shows the distribution of the type of dental trauma cases according to codes of EBDTI. There were significant differences between permanent and deciduous teeth with regard to uncomplicated and complicated crown fracture $(p<0.05)$. While uncomplicated crown fracture was the most common injury in permanent teeth (43.6\%), $85.9 \%$ of deciduous teeth had no crown fracture. There was no root fracture in a vast majority of traumatized permanent and deciduous teeth (95.5 and 97.4, respectively). Apical root fracture was the most common injury type in permanent and deciduous teeth (95.5 and 97.4, respectively). In terms of luxation injuries, while subluxation was the most common type in permanent teeth $(15.8 \%)$, subluxation and lateral luxation were mostly seen in deciduous teeth (30.8 and 28.2, respectively). In terms of maturity and shape of apex, most of the traumatized teeth in both dentitions had mature apex. There was no alveolar process fracture recorded for all cases.

While eleven teeth had both crown fracture and luxation injury, enamel fractures were observed in 2 and uncomplicated crown fractures in 9. Of these traumatized teeth, 6 had subluxation, 3 had lateral luxation, 1 had avulsion, and 1 had extrusion injuries. Only 3 of those teeth had mature apex.
The total number of teeth with root fractures in all teeth was 11. Apical root fracture was observed in 5 of these teeth, middle root frcature was seen in 3 , and cervical root fracture in 1 . While none of these teeth had luxation injuries, only 2 had complicated crown fractures.

Table 4 shows the distribution of traumatized teeth according to type of dentition. Maxillary first incisors were the most traumatized teeth in both dentitions. Figure 1 shows distribution of emergency treatment for traumatized permanent teeth. Regardless of tooth number, composite restoration was the most seen treatment type among traumatized permanent teeth. Figure 2 shows the distribution of emergency treatment for traumatized deciduous teeth. Review only was the most seen treatment type among deciduous teeth.

Figure 3 shows the distribution of traumatized teeth with luxation injuries according to maturity and shape of apex.

"While the total number of avulsed teeth was 19, 13 of those were permanent teeth. Nine of them were found in the place of dental trauma, 5 of them were stored dry. Only 4 of avulsed teeth were replanted in 30 min after dental trauma. The maxillary permanent central incisors were the most avulsed teeth recorded. The total number of avulsed deciduous teeth was 6 and none of avulsed deciduous teeth were replanted.

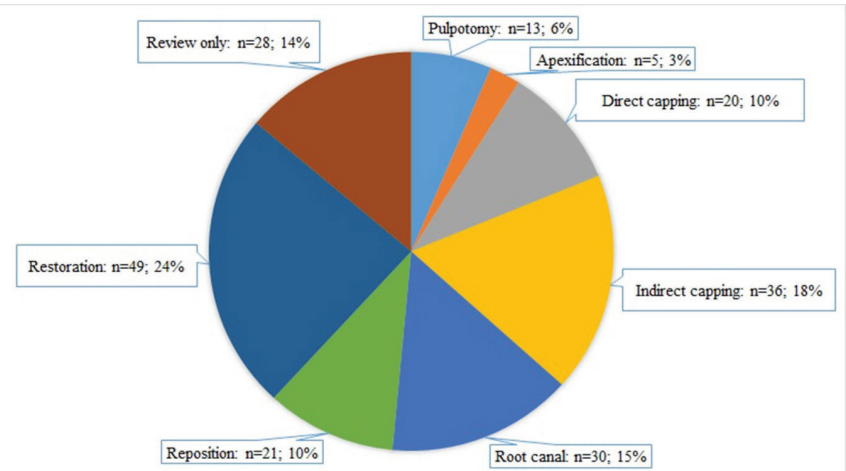

Figure 1. Distribution of emergency treatment for traumatized permanent teeth. 
Table 3. Distribution of dental trauma cases coded by Eden Baysal Dental Trauma Index

Codes

Permanent teeth

Deciduous teeth

\begin{tabular}{|c|c|c|c|c|c|}
\hline & & $\mathbf{n}$ & $\%$ & $\mathbf{n}$ & $\%$ \\
\hline \multicolumn{6}{|l|}{ 1st digit: Crown Fracture } \\
\hline Code 0 & None & 79 & 39.1 & 67 & 85.9 \\
\hline Code 1 & Enamel & 2 & 1.0 & 0 & 0 \\
\hline Code 2 & Uncomplicated crown* & 88 & 43.6 & 6 & 7.7 \\
\hline Code 3 & Complicated crown* & 33 & 16.3 & 4 & 5.1 \\
\hline Code 4 & Uncomplicated crown-root fracture & 0 & 0 & 0 & 0 \\
\hline Code 5 & Complicated crown-root fracture & 0 & 0 & 1 & 1.3 \\
\hline
\end{tabular}

2nd digit: Root Fracture

\begin{tabular}{rllccccc}
\hline Code 0 & None & 193 & 95.5 & 76 & 97.4 \\
\hline Code 1 & Apical 1/3 & 5 & 2.5 & 0 & 0 \\
\hline Code 2 & Middle 1/3 & 3 & 1.5 & 2 & 2.6 \\
\hline Code 3 & Cervical 1/3 & 1 & 0.5 & 0 & 0 \\
\hline
\end{tabular}

3rd digit: Luxation injuries

\begin{tabular}{|c|c|c|c|c|c|}
\hline $\mathrm{N}$ & None & 120 & 59.4 & 12 & 15.3 \\
\hline C & Concussion & 0 & 0 & 2 & 2.6 \\
\hline $\mathrm{S}$ & Subluxation & 32 & 15.8 & 24 & 30.8 \\
\hline $\mathrm{E}$ & Extrusive Luxation & 8 & 4.0 & 2 & 2.6 \\
\hline $\mathrm{L}$ & Lateral Luxation & 21 & 10.4 & 22 & 28.2 \\
\hline I & Intrusive Luxation & 8 & 4.0 & 10 & 12.8 \\
\hline$A$ & Avulsion & 13 & 6.4 & 6 & 7.7 \\
\hline
\end{tabular}

4th digit

Maturity of the root

\begin{tabular}{lllccccc}
\hline $\mathrm{i}$ & immature apex & 95 & 47.0 & 17 & 21.8 \\
\hline $\mathrm{m}$ & mature apex & 107 & 53.0 & 39 & 50.0 \\
\hline $\mathrm{r}$ & resorbed apex (physiological) & - & - & 22 & 28.2 \\
\hline
\end{tabular}

\section{5th digit}

\begin{tabular}{|cccccc}
\hline+ & presence of alveolar process fracture & - & - & - \\
\hline- & absence of alveolar process fracture & 202 & 100.0 & 78 & 100.00 \\
\hline * shows the statistically significance difference between dentition type, verified by Chi-squared test, $\mathrm{p}<0.05$ & & & \\
\hline
\end{tabular}

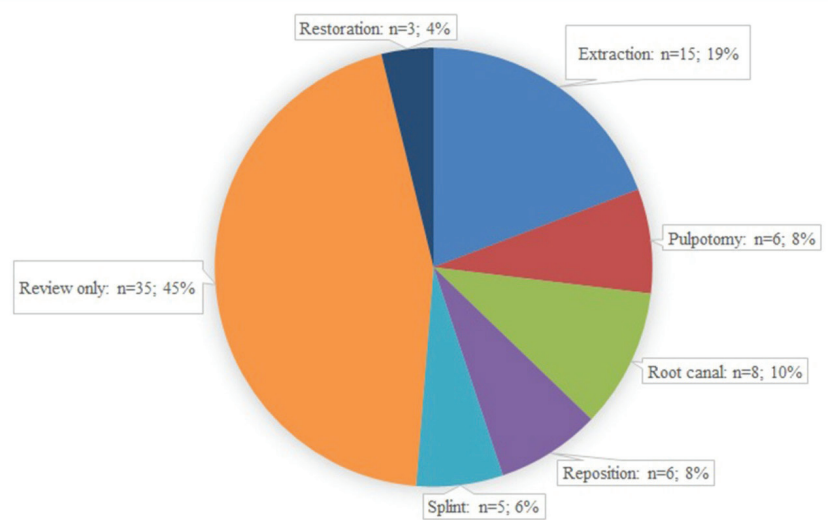

Figure 2. Distribution of emergency treatment for traumatized deciduous teeth.

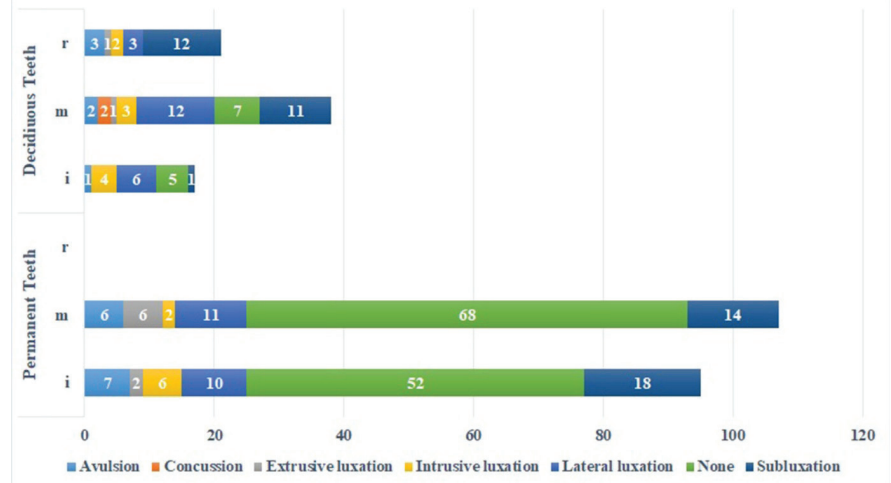

Figure 3. Distribution of traumatized teeth according to maturity of apex for luxation injuries. 
Table 4. Distribution of traumatized teeth according to type of dentition

\begin{tabular}{cccccc}
\multicolumn{2}{c}{ Permanent Teeth } & \multicolumn{4}{c}{ Deciduous Teeth } \\
\hline $\begin{array}{c}\text { Tooth } \\
\text { number }\end{array}$ & $\mathbf{n}$ & $\%$ & $\begin{array}{c}\text { Tooth } \\
\text { number }\end{array}$ & $\mathbf{n}$ & $\%$ \\
\hline 11 & 78 & 38.5 & 51 & 27 & 34.6 \\
\hline 12 & 17 & 8.4 & 52 & 5 & 6.4 \\
\hline 13 & 1 & 0.5 & 53 & 4 & 5.1 \\
\hline 14 & 1 & 0.5 & 54 & 1 & 1.3 \\
\hline 21 & 82 & 40.6 & 61 & 23 & 29.6 \\
\hline 22 & 8 & 4.0 & 62 & 4 & 5.1 \\
\hline 31 & 5 & 2.5 & 63 & 3 & 3.8 \\
\hline 32 & 1 & 0.5 & 71 & 4 & 5.1 \\
\hline 41 & 7 & 3.5 & 72 & 1 & 1.3 \\
\hline 42 & 2 & 1.0 & 81 & 5 & 6.4 \\
\hline & & & 82 & 1 & 1.3 \\
\hline Total & 202 & & & 78 & \\
\hline
\end{tabular}

\section{Discussion}

To our knowledge, this is the first study to describe prevalence and pattern of TDls using EBDTI in a web-based and multicenter design among Turkish children. This design also enabled to test the performance of EBDTI (22), which is a newly developed index to overcome the disadvantages of the present dental trauma classifications, in an epidemiological study.

With an online data collection form, data from four different centers were stored online and the results reached the researchers in the form of reports in Excel format. This data collection process allowed researchers to systematically and easily enter data, allowing online storage of collected data and more convenient reporting and evaluation of results. Similar to the previous studies $(24,27)$, using the web-based online application by researchers in different centers all over Turkey gives hope for a data collection and evaluation process at the national level.

The EBDTI is a useful tool to record the information about TDIs on different levels by means of only 5 digits following the FDI tooth code (22). Different characters as numbers, capital and lower case letters and simple signs rather than only numbers are used to code the information of the injury as digits make it simple to apply. First letters of the related words are used to make it easier and straightforward to remember. Trauma involving the dentoalveolar region can result in fractures and/or displacement of teeth and/or fractures of bone and/or soft tissue injuries often seen in combination. All of the injuries should be documented properly for further referral and treatment planning. The index has been structured to also contain the data such as location of root fracture, apex maturity, and fracture of alveolar process. Identifying all of this valuable information in a single index would surely help the clinician to manage TDls properly. As reported in the findings of the current study, EBDTI could record many different types of injuries at the same time and record their distribution with each other. This feature, which is different from the existing classifications in the literature, enables EBDTI to combine the assessment of crown, root, apex and alveolar conditions of injury types rather than a single type of injury. For example, how many teeth with crown fractures are accompanied by root fractures or the distribution of the crown fractures relative to the luxation injury can be easily recorded with this index. Although, a recent study (9) reported that multiple dental injuries, including supportive bone and soft tissue injuries, have been found to make up $1.8 \%-5 \%$ of the traumatic injuries among Turkish children, it failed to report the localization of the root fracture. Our study reported $3.9 \%$ multiple injuries with crown fracture and luxation injury within 6 months and it was also possible to report the localization of the root fracture in multiple injuries which is different from the previous epidemiological studies and is an advantage of the EBDTI.

As an important clinical feature, the maturity and shape of the apex plays an important role in the treatment plan of the traumatized tooth. On the other hand, treatment is closely related with the localization of root fracture and the accompanying injuries. Therefore, EBDTI will help clinicians select proper treatment according to the type of the injury and plan a follow-up schedule. The findings of this study reported that apical third root fracture was more common for the permanent dentition and 2 cases with middle third root fracture was recorded for primary teeth.

In accordance with other studies (15, 19, 23, 28, 29), this study also showed that the most frequently traumatized teeth were permanent maxillary incisors. This may be due to the position and angle of the maxillary incisors in the oral cavity, which makes them more predisposed to TDIs (12). No TDIs were observed in the posterior teeth. In this study, enamel-dentin fracture (uncomplicated) and subluxation were found to be the most common type of TDIs in permanent teeth. These findings are consistent with previous studies $(28,29)$.

Another important factor affecting the injury pattern is local biological factors (30). The alveolar bone is less mineralized and has higher flexibility in children (31), and the mechanical properties of teeth formed as a result of the permanent accumulation of dentin and cement by time cause changes in the occurrence and sequelae of trauma in deciduous and permanent teeth (32). If the damping effect of the tissues surrounding the root is increased, the energy transmission in a tooth changes following a pulse on the crown (33).Thus, energy from a trauma absorbable by a flexible bone and a large periodontal ligament in a child may cause root fracture in an adult $(34,35)$. Under the influence of all these clinical and demographic variables, the etiology of TDI is very complex and different in children with regard to deciduous and permanent teeth.

Permanent teeth were found to be more subjected to TDIs than deciduous teeth. This may be due to higher prevalence of TDls with increased age (36). There was also no significant correlation between TDIs and systematic disease or allergy. Consistent with previous studies $(4,9,29)$, this study found that boys were exposed to TDI more than girls. This could be due to males participating more in activities which require more physical activity, and having more leanings towards violence. With similar to previous studies $(9,15,36)$, this study revealed that 7-10 yr age group was found to be more subjected to dental trauma. 
School and house were the most common places where children were exposed to dental trauma. This may be because education was ongoing at schools in Turkey during most of the data collection period and children had spent majority of the time at school. Children also have more physical activity with their friends with increasing age, and act more uncontrollably in their peer environment. On the other hand, in very young age groups, children may be exposed to more TDls indoors because they spend more time at home. The main causes for dental trauma in children are falls and injuries sustained during play. These findings are supported by some previous studies in the literature $(9,10,15,16,28,37)$.

This study had several limitations. An important limitation was that the advantages or disadvantages of the web-based database application were not properly tested. Another limitation was the small sample size and data collection period. However, this study was designed as a pilot study. Future studies will be conducted in different centers and with larger sample sizes; as such, the validity of the findings should be supported. Another limitation was that many environmental factors and independent variables that could have an impact on TDIs were not evaluated. Future studies should examine whether there are any interactions between these variables and TDIs.

\section{Conclusion}

TDIs were significantly associated with age, gender, and type of dental trauma. Multiple dental injuries including hard and soft tissues were seen in $3.9 \%$ of all cases. Since TDIs are combination injuries involving several dental tissues, it has been found useful to use an index to facilitate the classification of these injuries, and to create a web-based records to facilitate the monitoring of TDI-related data in a single database and long-term, EBDTI promises the possibility of easy data collection worldwide.

Türkçe Özet: Eden Baysal Dental Travma Indeksi ile Web Tabanlı Dental Travma Veritabanı: Çok Merkezli Türk Çalışması. Amaç: Bu çalışmanın amacı web tabanlı ve çok merkezli bir çalışma dizaynında Eden Baysal Dental Travma Indeksi (EBDTI) kullanılarak Türk çocukları arasında travmatik diş yaralanmalarının (TDY) yaygınlığını tanımlamaktır. Gereç ve Yöntem: Çalışma örneklemi 1-15 yaş arasında ve dental travma geçirmiş hastalardan oluştu. EBDTI kullanarak hastaların klinik ve radyografik bulgularını kaydetmek için web tabanlı bir form geliştirildi. Elde edilen veriler hastanın cinsiyeti, travmanın tarihindeki yaşı, travma tarihi, yaralanma nedeni ve acil tedavi gibi değişkenler açısından incelendi. Veriler Pearson Ki-kare ve Fisher's kesin testleri kullanılarak analiz edildi. Bulgular: 252 hastada toplam 280 travma geçirmiş diş değerlendirildi. Dental travma erkeklerde ve 7-10 yaş grubunda daha fazla görüldü $(p<0,05)$. Daimi ve süt dişleri arasında komplike olmayan ve komplike kron kırığı görülme sıklığı açısından anlamlı fark bulundu ( $p$ $<0,05)$. Kök kırıkları çoğunlukla her iki dişlenme döneminde de kökün apikal üçlüsünde görüldü. Sonuç: TDY yaş, cinsiyet ve dental travma türü ile ilişkili bulundu. EDBTI, çoklu diş yaralanmalarının ve apeksin gelşiminin kolay ve uygun bir şekilde kaydedilmesini sağlamakta faydalı bulundu. Ayrıca, diş yaralanmalarının kayıtlarını kolaylaştırmak için web tabanlı uygulama yararlı bir yöntem olarak bulundu. Anahtar Kelimeler: dental travma, Eden Baysal Dental Travma Indeksi, travmatik dental yaralanmalar, web tabanlı veriler

Ethics Committee Approval: Ethical approval was obtained from Local Ethics Committee of Ege University, Turkey ( $\mathrm{No}=18-2 / 38)$.
Informed Consent: Informed consent was obtained from each patient.

Peer-review: Externally peer-reviewed.

Author contributions: $\mathrm{EE}, \mathrm{BB}, \mathrm{GD}$ and $\mathrm{SE}$ designed the study. $\mathrm{EE}, \mathrm{BB}$, $G D$ and $S E$ participated in generating the data for the study $E E, B B$, GD and SE participated in gathering the data for the study. BB participated in the analysis of the data. $E E$ and $B B$ wrote the majority of the original draft of the paper. : $E E, B B, G D$ and $S E$ participated in writing the paper. All authors approved the final version of this paper.

Conflict of Interest: Authors declared no conflict of interest.

Financial Disclosure: The authors declared that they have received no financial support.

\section{References}

1. Petti S, Glendor U, Andersson L. World traumatic dental injury prevalence and incidence, a meta-analysis-One billion living people have had traumatic dental injuries. Dent Traumatol 2018;34:71-86. [CrossRef]

2. Abanto J, Paiva SM, Raggio DP, Celiberti P, Aldrigui JM, Bönecker $M$. The impact of dental caries and trauma in children on family quality of life. Community Dent Oral Epidemiol 2012;40:323-31. [CrossRef]

3. Buldur B, Guvendi ON. Conceptual modelling of the factors affecting oral health-related quality of life in children: A path analysis. Int J Paediatr Dent 2020;30:181-92. [CrossRef]

4. Lam R. Epidemiology and outcomes of traumatic dental injuries: a review of the literature. Aust Dent J 2016;61:4-20. [CrossRef]

5. Fakhruddin KS, Lawrence HP, Kenny DJ, Locker D. Impact of treated and untreated dental injuries on the quality of life of Ontario school children. Dent Traumatol 2008;24:309-13. [CrossRef]

6. Ahmad P, Abbott PV, Alam MK, Asif JA. A bibliometric analysis of the top 50 most cited articles published in the Dental Traumatology. Dent Traumatol 2020;36:89-99. [CrossRef]

7. Sharif MO, Tejani-Sharif A, Kenny K, Day PF. A systematic review of outcome measures used in clinical trials of treatment interventions following traumatic dental injuries. Dent Traumatol 2015;31:422-8. [CrossRef]

8. Kenny KP, Day PF, Sharif MO, Parashos P, Lauridsen E, Feldens CA, Cohenca N, Skapetis T, Levin L, Kenny DJ. What are the important outcomes in traumatic dental injuries? An international approach to the development of a core outcome set. Dent Traumatol 2018;34:4-11. [CrossRef]

9. Kırzıoglu Z, Oz E. Changes in the aetiological factors of dental trauma in children over time: An 18-year retrospective study. Dent Traumatol 2019;35:259-67. [CrossRef]

10. Fonseca RCLd, Antunes JLF, Cascaes AM, Bomfim RA. Individual and contextual factors associated with traumatic dental injuries in a population of Brazilian adolescents. Dent Traumatol 2019;35:171-80. [CrossRef]

11. Fernandes $L M$, Neto JCL, Lima TF, Magno MB, Santiago BM, Cavalcanti YW, de Almeida LdFD. The use of mouthguards and prevalence of dento-alveolar trauma among athletes: A systematic review and meta-analysis. Dent Traumatol 2019;35:54-72. [CrossRef]

12. Primo-Miranda EF, Ramos-Jorge ML, Homem MA, de Souza DS, Stetler AD, Ramos-Jorge J, Marques LS. Association between occlusal characteristics and the occurrence of dental trauma in preschool children: a case-control study. Dent Traumatol 2019;35:95-100. [CrossRef]

13. Buldur B, Kapdan A. Factors Associated with Knowledge and Attitude of Management of Traumatic Dental Injuries: A Cross-Sectional Study among Turkish Dentists. Pesqui Bras Odontopediatria Clin Integr Title 2018;18:3948-56. [CrossRef] 
14. Tello G, Bonini GC, Murakami C, Abanto J, Oliveira LB, Bönecker $M$. Trends in the prevalence of traumatic crown injuries and associated factors in Brazilian preschool children: 10-year observational data. Dent Traumatol 2016;32:274-80. [CrossRef]

15. Damé-Teixeira N, Alves LS, Susin C, Maltz M. Traumatic dental injury among 12-year-old South Brazilian schoolchildren: prevalence, severity, and risk indicators. Dent Traumatol 2013;29:52-8. [CrossRef]

16. Goettems ML, Torriani DD, Hallal PC, Correa MB, Demarco FF. Dental trauma: prevalence and risk factors in schoolchildren. Community Dent Oral Epidemiol 2014;42:581-90. [CrossRef]

17. Andreasen JO, Lauridsen E, Gerds TA, Ahrensburg SS. Dental Trauma Guide: A source of evidence-based treatment guidelines for dental trauma. Dent Traumatol 2012;28:345-50. [CrossRef]

18. Eyuboglu O, Yilmaz Y, Zehir C, Sahin H. A 6-year investigation into types of dental trauma treated in a paediatric dentistry clinic in Eastern Anatolia region, Turkey. Dent Traumatol 2009;25:110-4. [CrossRef]

19. Zaleckiene V, Peciuliene V, Brukiene V, Drukteinis S. Traumatic dental injuries: etiology, prevalence and possible outcomes. Stomatologija 2014;16:7-14.

20. GlendorU,MarcenesW, Andreasen J.Classification, epidemiology and etiology. Textbook and color atlas of traumatic injuries to the teeth. 5th Ed. Oxford,UK: Wiley-Blackwell 2018.

21. Andreasen JO, Andreasen FM, Andersson L. Textbook and color atlas of traumatic injuries to the teeth. 4th Ed., Oxford,UK: WileyBlackwell 2018. [CrossRef]

22. Eden $E$, Baysal M, Andersson L. Eden Baysal Dental Trauma Index: Face and Content Validation. Dent Traumatol 2020;36:117-23. [CrossRef]

23. Tsilingaridis G, Malmgren B, Andreasen JO, Wigen TI, Maseng Aas AL, Malmgren O. Scandinavian multicenter study on the treatment of 168 patients with 230 intruded permanent teeth-a retrospective cohort study. Dent Traumatol 2016;32:353-60. [CrossRef]

24. Oldin A, Lundgren J, Nilsson $M$, Norén JG, Robertson A. Traumatic dental injuries among children aged $0-17$ years in the BITA study-A longitudinal Swedish multicenter study. Dent Traumatol 2015;31:9-17. [CrossRef]

25. Day PF, Duggal MS, Kiefte B, Balmer RC, Roberts GJ. The role for 'reminders' in dental traumatology: 4. The use of a computer database for recording dento-alveolar trauma in comparison to unstructured and structured paper-based methods. Dent Traumatol 2006;22:265-74. [CrossRef]

26. Seckelmann A. Domestic tourism-a chance for regional development in Turkey? Tour Manag 2002;23:85-92. [CrossRef]

27. Zaror C, Espinoza-Espinoza G, Atala-Acevedo C, Muñoz-Millán P, Li Y, Clarke K, Onetto J, Díaz J, Hallet K, Manton D. Validation and usability of a mobile phone application for epidemiological surveillance of traumatic dental injuries. Dent Traumatol 2019;35:33-40. [CrossRef]

28. Atabek D, Alaçam A, Aydintuğ I, Konakoğlu G. A retrospective study of traumatic dental injuries. Dent Traumatol 2014;30:15461. [CrossRef]

29. Lauridsen E, Hermann NV, Gerds TA, Kreiborg S, Andreasen JO. Pattern of traumatic dental injuries in the permanent dentition among children, adolescents, and adults. Dent Traumatol 2012;28:358-63. [CrossRef]

30. Andreasen J. Etiology and pathogenesis of traumatic dental injuries A clinical study of 1,298 cases. Eur J Oral Sci 1970;78:32942. [CrossRef]

31. Öhman C, Baleani M, Pani C, Taddei F, Alberghini M, Viceconti M, Manfrini M. Compressive behaviour of child and adult cortical bone. Bone 2011;49:769-76. [CrossRef]

32. Lim WH, Liu B, Mah SJ, Chen S, Helms JA. The molecular and cellular effects of ageing on the periodontal ligament. J Clin Periodontol 2014;41:935-42. [CrossRef]

33. Huang H-M, Tsai C-Y, Lee H-F, Lin C-T, Yao W-C, Chiu W-T, Lee S-Y. Damping effects on the response of maxillary incisor subjected to a traumatic impact force: a nonlinear finite element analysis. J Dent 2006;34:261-8. [CrossRef]

34. Arraj GP, Rossi-Fedele G, Doğramacı EJ. The association of overjet size and traumatic dental injuries-a systematic review and meta-analysis. Dent Traumatol 2019;35:217-32. [CrossRef]

35. Bonini GC, Bönecker M, Braga MM, Mendes FM. Combined effect of anterior malocclusion and inadequate lip coverage on dental trauma in primary teeth. Dent Traumatol 2012;28:437-40. [CrossRef]

36. Skaare AB, Jacobsen I. Dental injuries in Norwegians aged 7-18 years. Dent Traumatol 2003;19:67-71. [CrossRef]

37. Hunter M, Hunter B, Kingdon A, Addy M, Dummer P, Shaw W. Traumatic injury to maxillary incisor teeth in a group of South Wales school children. Dent Traumatol 1990;6:260-4. [CrossRef] 